\title{
The Truth in Architecture as a Synthesis of Material and Ideas - Brick Architecture of Białystok
}

\author{
Andrzej Tokajuk \\ https://orcid.org/0000-0002-7532-6414 \\ a.tokajuk@pb.edu.pl \\ Faculty of Architecture, Bialystok University of Technology
}

\begin{abstract}
In contemporary architecture, the problem of the truth and lies can be considered in several aspects - form, idea, material, also in terms of beauty and aesthetics. The aim of this article is to show that the truth in architecture can be interpreted as a kind of synthesis of material and ideas. Such synthesis occurs, inter alia, in the architecture of buildings with brick facades. The author of the text carries out the case studies analysis on the example of the brick architecture of Białystok from the $19^{\text {th }}$ and $20^{\text {th }}$ centuries - among which several outstanding works of architecture can be identified. The result of the research is the confirmation of the thesis put at the beginning and the presentation the evolution of the forms of brick architecture in Białystok in the $19^{\text {th }}$ and $20^{\text {th }}$ centuries.
\end{abstract}

Keywords: brick, architecture, truth, Białystok

\section{Introduction}

Architecture has a long tradition in searching for the truth. The truth is timeless. In philosophy, mathematics, and other sciences - truths are permanent, they last for years, sometimes centuries. Sometimes the truth changes as a result of scientific discoveries or civilization changes, and the evidence and claims are updated. How to understand the concept of truth in contemporary architecture? This issue is complex and ambiguous. It is not always possible to state in a specific case of an architectural thing that we are dealing with the truth or a lie. There is truth, there are half-truths, and there is also the truth that is not fully told - the untold truth is not the same as saying untruth. Contemporary architecture is dominated by untruth, in all its diversity with many conflicts between nature and culture, tradition and modernity, form and function, form and structure, form and meaning, universalism and regionalism [Włodarczyk, 2009]. These conflicts occur simultaneously on many levels and make it much more difficult to understand contemporary architectural works, thus making it difficult to find the truth in architecture. Artists believe in the existence of truth in art, also in architecture. In the past, the issue of truth played a significant role, trends in architecture were based on a certain ethics, the architectural form resulted from certain ideological assumptions and was related to the adopted type of aesthetics, with a specific canon of beauty. According to many authorities, the truth can be found in ancient architecture, in the architecture of the Gothic and Renaissance periods, but also in the architecture of modernism, brutalism, etc.

It seems that one of the criteria for the existence of truth is also the time, which verifies the aging process of architecture. It is the influence of time that causes the architecture of some buildings to deteriorate prematurely, they become kitsch, only construction. How is it today? Can it even talk about the existence of the truth in architecture?

Today, architecture is expressed as originality, and original forms are mainly created thanks to the sophisticated design methods used by some architects. The search for a sophisticated form results from the fact that nowadays it is the form that has become the most important. In this article, the author will attempt to analyze 
the thesis that the truth in architecture can be found in brick architecture - it is timeless, there is a synthesis of material and ideas (understood as a way of manipulating material, as a vision of form, a reference to tradition, a way of shaping a detail), etc.). The author's analysis is based on the example of selected buildings of brick architecture in Białystok from the $19^{\text {th }}$ and $20^{\text {th }}$ centuries.

Brick as a material for creating architecture has been known for centuries, made of clay, shaped by human hands - friendly and healthy. "Holy brick" - as professor Konrad Kucza-Kuczyński writes [Kucza-Kuczyński, 2012], and he immediately adds "brick ... is a symbol of eternity in architecture" [Kucza-Kuczyński, 2012], which means that brick architecture can be timeless and honest. We can find brick buildings in different periods of architectural development, in antiquity and in the Middle Ages, they were commonly built of brick for many centuries in Scandinavian countries, in Netherlands, Germany, brick facades were also designed by famous architects of the $20^{\text {th }}$ century - e.g. Alvar Aalto, Mario Botta and others [Tietz, 2001; Gossel, Leuthauser, 2012]. Many buildings made of brick can also be found in Poland, including the Podlasie region, where, thanks to the clay deposits, this material has also been used quite widely for many years.

\section{The development of brick architecture in Białystok at the turn of the $19^{\text {th }}$ and $20^{\text {th }}$ centuries}

The development of brick architecture in Podlasie and Białystok on a large scale can be noticed in the $19^{\text {th }}$ century. Although the foundations for this development were probably created by the Military School of Construction and Engineering, founded in 1745 in Białystok by Jan Klemens Branicki, who from 1752 held the highest military function in $18^{\text {th }}$-century Poland - the Grand Hetman of the Crown. The school, which existed until 1771 , as the only one in Poland at that time, educated about 300 engineers. The lecturers were civil officers and professors, mostly foreigners, because the country lacked senior staff. Typically military subjects as well as technical and general subjects were taught, including civil and military architecture, surveying, melioration, mathematics, geometry, history, foreign languages, military exercises. Practical classes were held at nearby construction sites. The school existed for 25 years, education lasted 3 years, and its graduates, leaving its walls with a military rank, chose the military service or work as administrators, officials and architects. But it was in the nineteenth century that political and economic changes took place in Podlasie, which caused the dynamic development of construction. Apart from wooden buildings, brick buildings, faced with yellow and red bricks, began to be built in Białystok and the region. Brick architecture can also be found in other Polish and European cities from this period, but many such facilities have been built on Podlasie. The oldest of them come from the $19^{\text {th }}$ century. At that time, Białystok, after the third partition of the country, was under Prussian occupation, and from 1807 - by Russia. An administrative customs border was introduced between the Kingdom of Poland and the territories incorporated directly into Russia - this initiated the development of industry in Białystok and its vicinity. Industrialists began to arrive to the city, from Łódź and other Polish cities, investments were started by capital in the hands of Jewish and German manufacturers. The first textile factories started to appear, goods were exported mainly to the East. In addition to industrial facilities, military facilities were also built - garrison buildings. The development of Białystok in the nineteenth and early twentieth centuries was dominated by three factors: industry, army and trade.

The architecture of the first industrial and military buildings in Białystok was quite austere, massive, simple forms were erected with very reduced detail. These buildings were built of industrial-scale red brick, and over time, yellow bricks also appeared in use. Initially, brick objects were monochromatic, with time, expressive details began to be used in the facades: pilasters, cornices, decorative door and window frames, attics and pedestals, projections, entrances and corners were decorated. Triangular tympana was made of brick, the windows were crowned with decorative arched details with a characteristic keystone. All this required great brickwork and masonry skills, careful grouting of the walls, precision, perfect - for those times, the composition of the facade and the arrangement of the geometry of details. This architecture was genuine and honest, leaving no room for error. An example of an implementation from that period is, among others: the factory complex of Eugeniusz Becker Society of Białystok Manufacture at Świętojańska Street. Some buildings from this assumption have survived to this day - also the most outstanding of them, the so-called Mercury building, they were incorporated into the revitalization project of the factory into the shopping mall Alfa (2007-2008, design by architect 
M. Kuryłowicz) [Tokajuk, Tokajuk, 2019]. The first factory buildings were built in 1883, but the so-called Mercury building was built as a finished goods warehouse in 1911. Preserved to this day, it was the most representative building of the factory, situated along Świętojańska Street. The three-storey building is made of red brick and has outstanding architectural value. The horizontally stretched multi-axis facade has a rich brick detail. The symmetrical facade is divided with cordon cornices and crowned with a crowning cornice. The central avant-corps are decorated with delicate arches, vertical blendes, pilasters, cornices, and topped with a sculpture of Mercury. The historicizing arcades in the gable made of brick form a kind of Neo-Romanesque quadrophorium. (Fig.1)
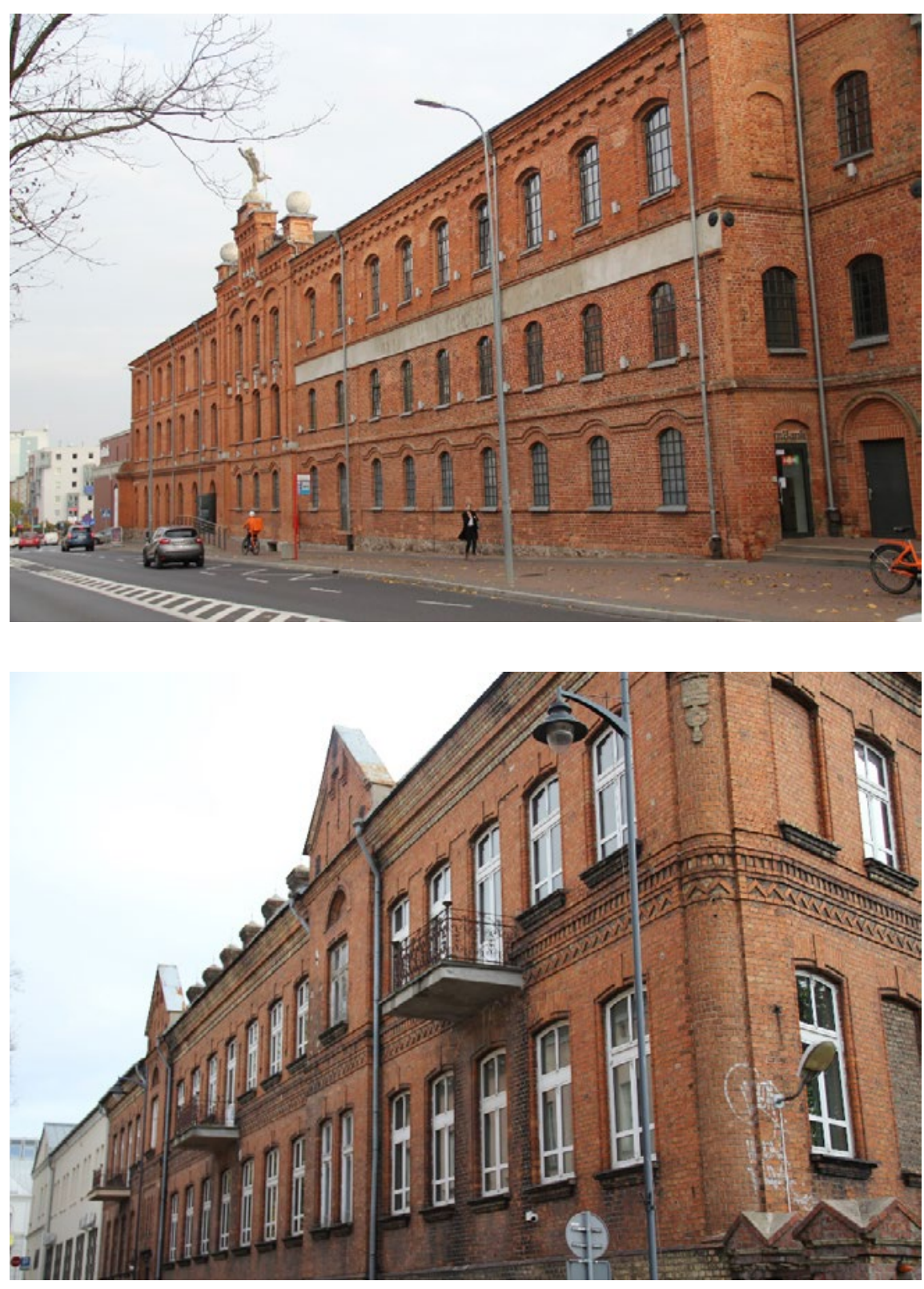

Fig. 1. The Mercury building from the factory complex of the Eugeniusz Becker Society of Białystok Manufacture at Świętojańska Street - the current state. Photo: Andrzej Tokajuk

Fig. 2. The building of the former Juliusz Flaker textile factory (now a technical telecommunications building, Kościelna Street - two-story building represents outstanding architectural values, built of red brick, with the use of yellow brick only in the eaves cornice present condition. Photo: Andrzej Tokajuk

The development of the brick architecture of the city took place in the second half of the nineteenth century, two colors of bricks were used on the facades at the same time, with yellow bricks for facing the walls, and red - for decorative elements. There was even an administrative order to use two types of bricks on the facades of public buildings in Białystok in 1861 (in the terms of the tender for the renovation of municipal guard facilities). The development of this type of brick construction in Białystok region and in the city itself was 
contributed by the establishment of several brickyards in the vicinity of the city - in Horodniany (in 1884) and in Księżyno (late $19^{\text {th }}$ century), producing for local needs.

Examples of the one-color brick architecture of Białystok from the turn of the $19^{\text {th }}$ and $20^{\text {th }}$ centuries include building of the former Juliusz Flaker textile factory - currently a technical telecommunications building, Kościelna Street (Fig. 2), barracks buildings, industrial buildings (e.g. factory complexes of Chana Marejn and Wolf Zilberblatt at Częstochowska and Włókiennicza Streets, residential and industrial complex of Izaak Sztejn at Poleska Street, etc.), the building of the Zinaida Chwoles female gymnasium at Pałacowa Street 3 (now the location of the National Health Fund), etc. [Dolistowska, 2009]. The single-color buildings were built until the outbreak of World War I.
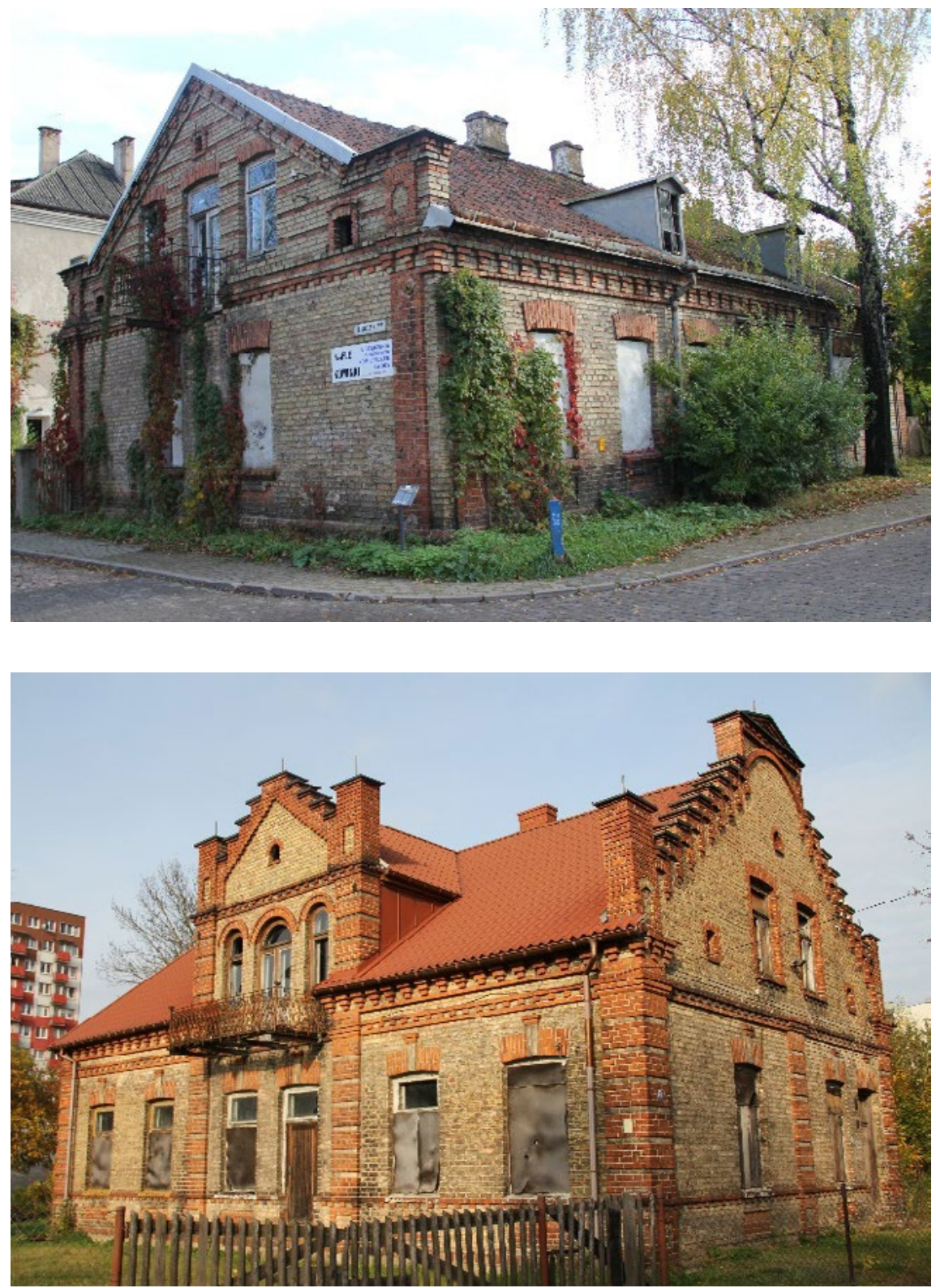

Fig. 3. House at Staszica Street - the present state (on the left). Photo: Andrzej Tokajuk
Fig. 4. House at Grunwaldzka Street - the present state (on the right). Photo: Andrzej Tokajuk

Over time, the local population began to get richer and the owners - investors - began to use facing bricks to build single-family houses and multi-family tenement houses. Examples of architecture of such buildings include: residential houses at Staszica, Poprzeczna, Mazowiecka, Grunwaldzka Streets and in other places (many 
of such buildings have been ruined). The forms of brick single-family houses were modeled on the forms of wooden architecture, the houses had residential attics, the gables were finished with stepped finials, the elevations were decorated with cornices, etc. (Fig. $3 \& 4$ )

At the end of the nineteenth century, yellow and red facades made of veneer bricks can be found in buildings with the following functions: residential, farm, villas, tenement houses, public utility buildings, industrial and factory facilities, barracks, and churches. (Fig. 5) After about a hundred years - at the beginning of the $21^{\text {st }}$ century - the brick buildings of Białystok from the end of the $19^{\text {th }}$ and the beginning of the $20^{\text {th }}$ century and the way of using the facing bricks on their facades were called the Białystok Brickwork School [Turecki, 2003].

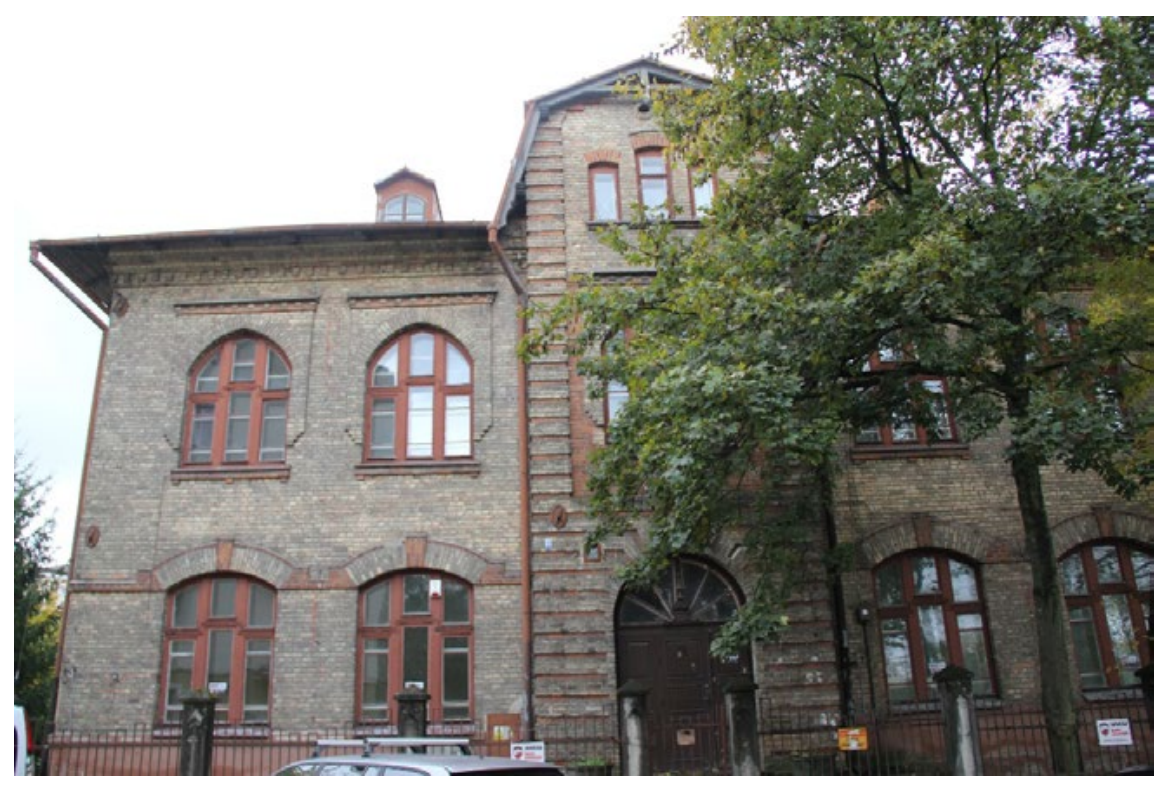

Fig. 5. Jewish religious school in the Talmud Tory school complex, Lipowa Street - the current state. The characteristic facade is made of two-color brick. Photo: Andrzej Tokajuk

\section{The development of brick architecture in Białystok at the beginning of the $20^{\text {th }}$ century - neo-styles}

In the brick architecture of Białystok at the beginning of the $20^{\text {th }}$ century, we can find most of the stylistic trends that appeared in the first decades of this century in Polish and European architecture. Among the buildings built at that time, a few very valuable works of architecture should be emphasized, such as: the Neo-Gothic cathedral church of Assumption of the Blessed Virgin Mary, the Neo-Romanesque Evangelical-Augsburg church of St. John the Baptist (now the Roman Catholic Church of St. Adalbert), the Neo-Renaissance building of the Board of the Society of Białystok Manufacture „Eugeniusz Becker and Co." at Świętojańska Street, the Neo-Renaissance Hasbach Palace in the district of Dojlidy. The Neo-Gothic cathedral church was built in years 1900-1905, based on a design by Józef Pius Dziekoński from 1896 [Jabłoński, 2008; Kłopotowska, Kłopotowski, 2015]. The church was designed in the so-called a great cathedral form, referring in style to the Gothic, which in Poland under the partitions became the quintessence of Polish national architecture. The two-tower, threenave basilica was built of red brick with the addition of stone. The fragmented body was reinforced with buttresses with buttresses, a soaring turret was placed at the intersection of the transept and the nave, the walls of the transept are crowned with stepped gables with pinnacles. The building has two towers, and its main facade is decorated with three pointed portals. Brick details were also designed inside the church, incl. in the form of brick ribs of vaults, framing of inter-nave arcades as well as window and door openings. Undoubtedly, the synthesis of the material materializes perfectly in the ideas of this neo-gothic building - as a result, we get an architecture that has an element of truth in it. (Fig. 6) 


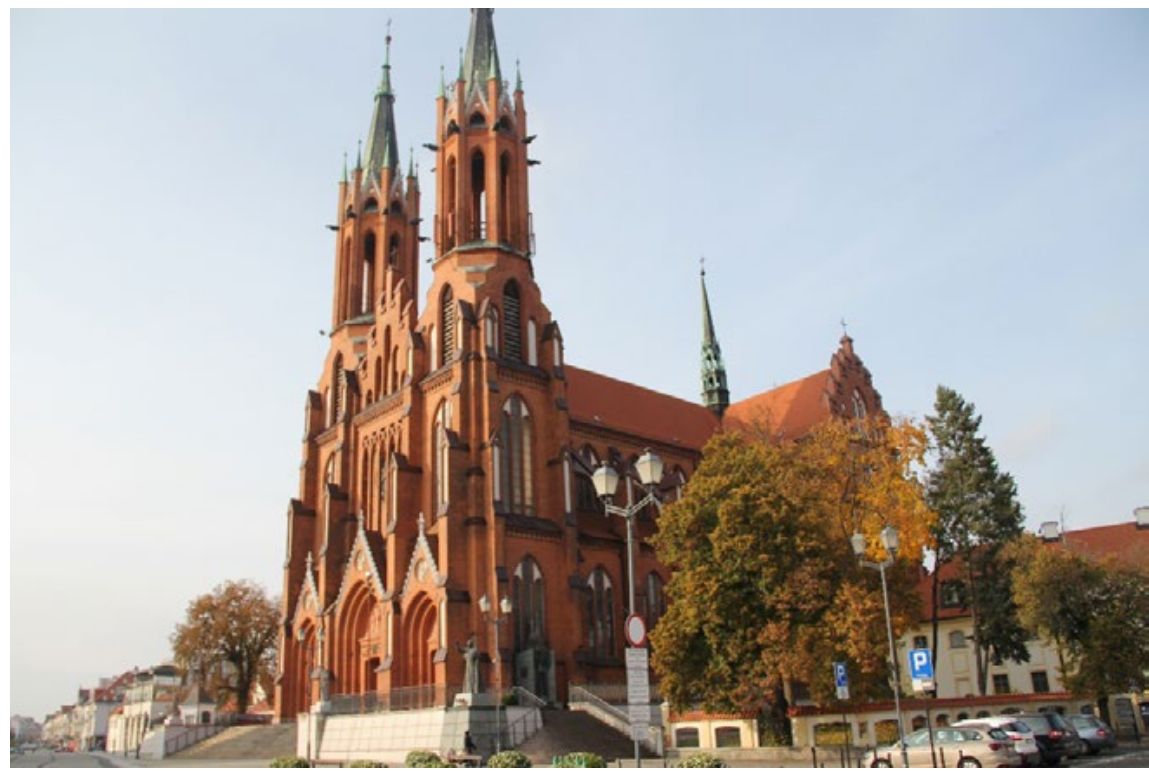

Fig. 6. Neo-Gothic cathedral church of Assumption of the Blessed Virgin Marypresent state. Photo: Andrzej Tokajuk

Another very expressive example of honest architecture with high architectural value is the neo-Renaissance seat of the Society of Białystok Manufacture „Eugeniusz Becker and Co.". It is a renaissance-style building, two-storey, on a rectangular plan with a tower in the corner. The building has facades faced with red brick, with the division of the facade made in plaster imitating sandstone. The architectural qualities of the building are emphasized by: an asymmetrical body with a mansard roof, a rich neo-Renaissance detail (banquets, cabochons, dormers, eye crop, etc.). Similar solutions known as the "French costume" can be found, among others in the palace at Foksal Street in Warsaw. It is a very expressive architecture, honestly expressing the ideas of the Neo-Renaissance through a masterful handling of materials and details. (Fig. 7)

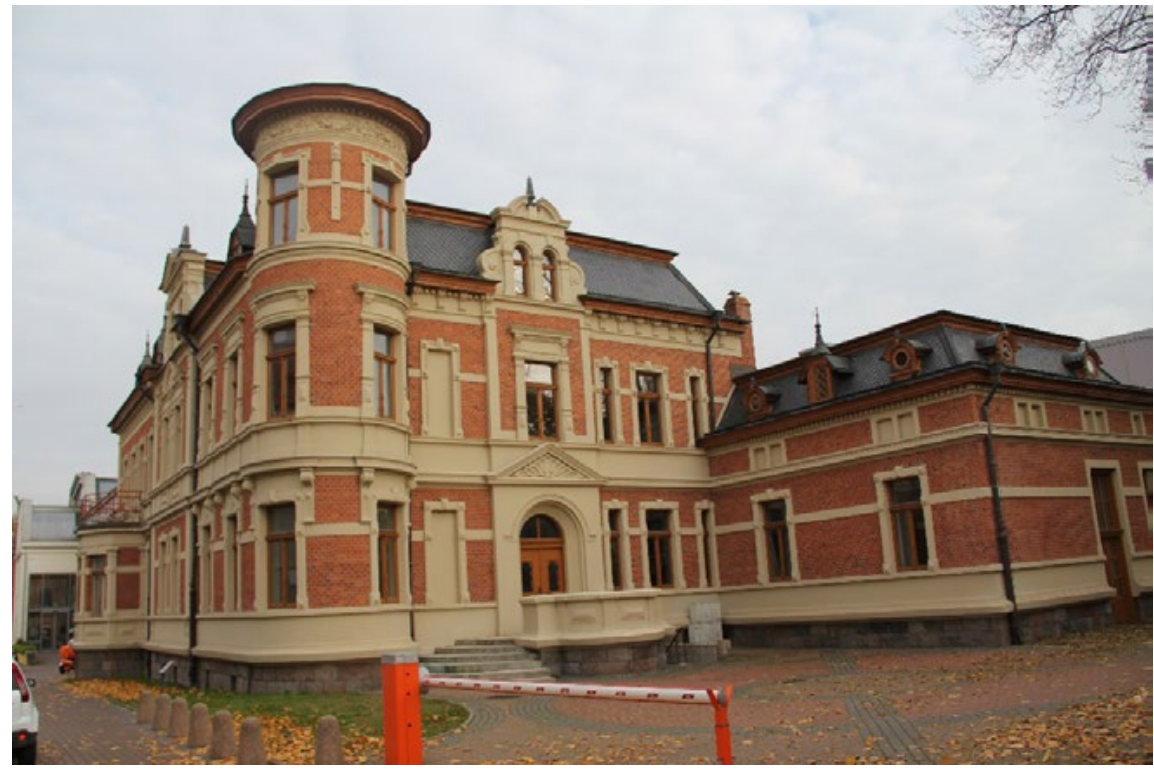

Fig. 7. Neo-Renaissance seat of the Society of Białystok Manufacture "Eugeniusz Becker and Co.", Świętojańska Street present state. Photo: Andrzej Tokajuk

Among the buildings erected in Białystok in the beginning of the $20^{\text {th }}$ century, architecture with Ruthenian-Byzantine influences should also be noted - on the example of the garrison church at ul. View (now the Church of St. Stanislaus the Bishop), as well as buildings in the modernist trend: the military warehouse complex at Węglowa Street and buildings of the Fajwel Janowski tobacco factory at Modlińska - Warszawska Streets. 
The most numerous, however, are objects that do not show clear features of belonging to any of the varieties of historicism. The architectural divisions of their elevations are used to emphasize the tectonics of the building, cornices and friezes divide the elevations into storeys, pilasters and pilaster strips (usually in a small order) - they introduce alignment. Details, sometimes rich, were introduced into such frames, emphasizing the corners of the buildings. On the other hand, buildings in the modernist spirit are characterized by smooth, ascetic facades, emphasizing the functionalistic character of such architecture. In this case, there is no room for decorative details. (Fig. 8)

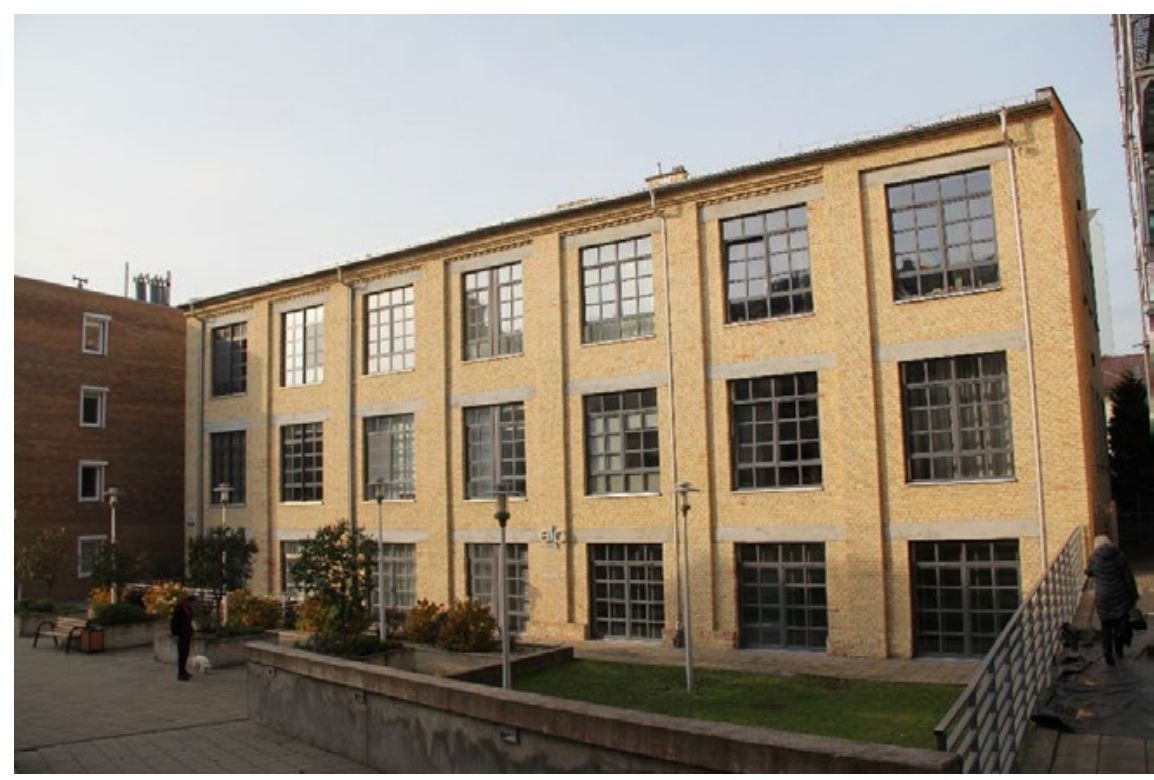

Fig. 8. One of the preserved buildings in the complex of the former Fawel Janowski tobacco factory - present condition. Currently it serves residential functions. Object after renovation. Photo: Andrzej Tokajuk

\section{The second wave of brick architecture in Białystok in the end of the $20^{\text {th }}$ century}

The outbreak of World War II, followed by the advent of socialist realism, meant that for almost 50 years no significant architectural object was built in Białystok, the construction of which would use facing bricks in the facades. All architectural achievements at the turn of the nineteenth and twentieth centuries were halted, there was a departure from this style. Nationalization after World War II destroyed the craft tradition, and from the end of the 1960s, the construction industry was marginalizing the creative freedom of architects. The development of prefabricated technologies and the construction of large housing estates using industrialized methods have limited the artistic and individual approach to architecture. Sticking to a brick has become a symbol of resistance to industrialized building technologies. Brick played a great role in preserving the ethos of building craftsmanship and individual architecture. Brick requires use in accordance with the canons of art, but also allows you to work on details. Clay - earth shaped by a human hand and burnt in fire - becomes in the 1980s a symbol of the relationship with nature, landscape and the region, and brick buildings constitute the identity of architecture in a given place. The use of brick in architecture design in the end of the $20^{\text {th }}$ century signaled an attachment to tradition, and it became fashionable again among some architects, especially those who reluctantly looked at the covers of architectural magazines, full of concrete or glass facades. It turned out that brick architecture became an important trend again. This also applies to Białystok's architecture. In the end of the $20^{\text {th }}$ century, some architects began to design using facade bricks - important public buildings, churches, and houses with brick facades and details began to be built, it happened also in Białystok. Some outstanding works of architecture on a European scale have been created - including The Orthodox Church of St. Spirit, designed by architect Jan Kabac and The Orthodox Church of God's Wisdom - Hagia Sophia, designed by 
architect Michał Bałasz. There are more examples, but these two churches clearly prove the correctness of the thesis that the truth and honesty of architecture is a synthesis of material and ideas.

The first of the above-mentioned objects - The Orthodox Church of St. Spirit is the largest Orthodox Church in Poland, it was designed to commemorate the $1000^{\text {th }}$ anniversary of the baptism of Eastern Christianity. Its construction began in the 1980s, the author of the design is one of the most outstanding architects from Białystok - Jan Kabac. The temple is unique in terms of architecture, it has become - next to the Branicki Palace and the Church of St. Roch - the most recognizable building in Białystok. The symbolism of the church architecture refers to the summoning of the church. Designed on a central plan, its walls and domes have the shape of tongues of fire, in the form of which the Holy Spirit descended on the apostles. The five domes refer to Jesus and the four evangelists. The nave of the church has an octagon plan with an area of 800 square meters, and the total area is 2,250 square meters. The temple can accommodate 2,500 believers. Elevations of the church of St. Spirit are made of sand-yellow facing bricks, the framing of walls is also made of bricks - tongues of fire, walls of different heights surrounding the central dome. It causes the effect of growing, piling up and dynamics of the form. Already in the $21^{\text {st }}$ century, a bell tower was built next to the church (also using clinker bricks). The outstanding object was created, where the material and idea (eastern canons) found their synthesis. (Fig. 9)

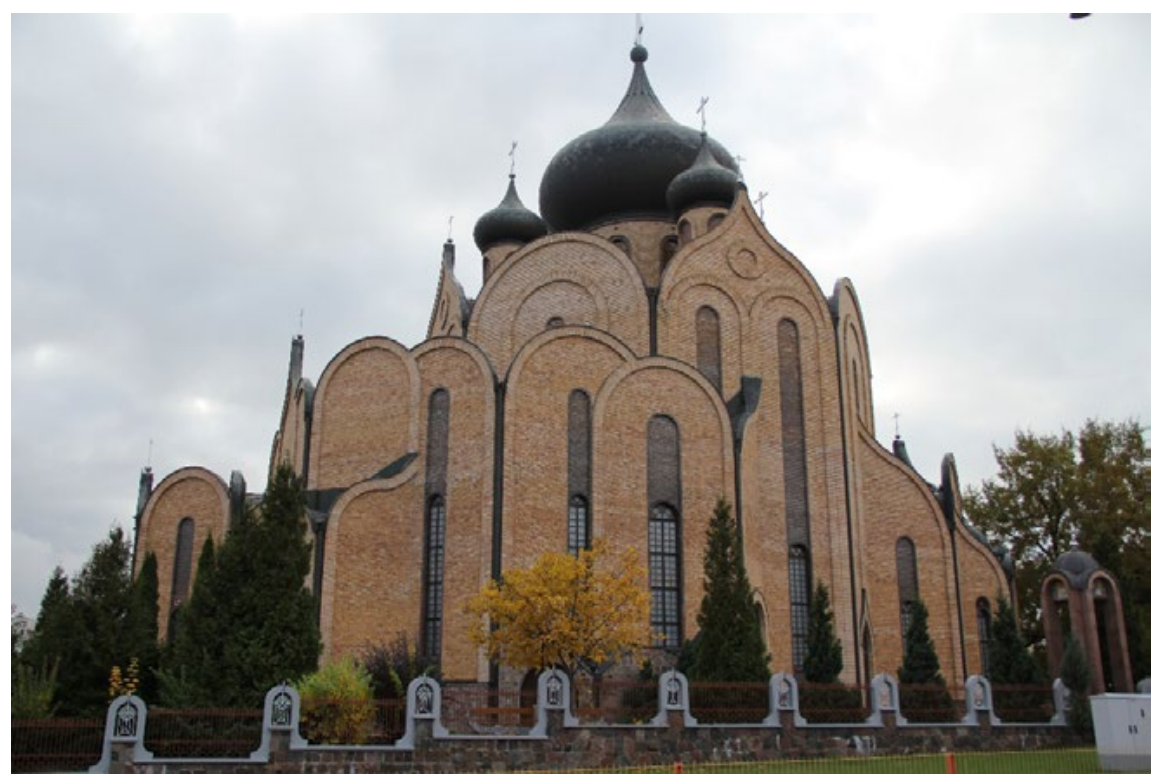

Fig. 9. The Orthodox Church of St. Spirit in Białystok - a view. Photo: Andrzej Tokajuk

\section{Conclusion}

The analysis carried out by the author of the text clearly confirms the thesis put forward in the beginning, that brick architecture contains an element of truth, continuity, humanism, and in combination with the idea it gives a great effect of the spirit of place and continuation of identity. In today's world of contemporary architecture with smooth facades and often incomprehensible forms - brick architecture is timeless. Objects built of brick in Białystok in various times - despite the passage of time, changing ideas and stylistic tendencies - give a sense of the identity of place, the truth of forms and details. And although the brick architecture of Białystok from the $19^{\text {th }}$ century did not leave many outstanding implementations - it became a great foundation for historicising objects from the beginning of the $20^{\text {th }}$ century and for works of architecture in the end of the $20^{\text {th }}$ century. Undoubtedly, the analysis of the architectural values of buildings constructed in Białystok in the last decade of the $20^{\text {th }}$ century and first years of the $21^{\text {st }}$ century, buildings with brickwork in elevations, requires - due to the scope of the issue - a separate study and further research.

It seems that brick can also be an inspiring material for the idea of sustainable development in the $21^{\text {st }}$ century. According to professor Konrad Kucza-Kuczyński: „Brick is: eternal - free - alive - eco and sustainable” 
[Kucza-Kuczyński, 2012]. But the $21^{\text {st }}$ century architecture, in the times of savings on the construction process, widespread use of concrete and designing cheap external walls of buildings - has brick architecture a chance to continue and survive?

The research was carried out as part of work No. WZ/WA - IA/4/2020 at the Bialystok University of Technology and financed from a research subsidy provided by the Minister of Science and Higher Education.

\section{References}

[1] Dolistowska M., W poszukiwaniu tożsamości miasta. Architektura Białegostoku w latach 1795-1939, Oficyna Wydawnicza Politechniki Białostockiej, Białystok 2009, p. 168-170.

[2] Jabłoński K.A., Biały i czerwony. Kościoły białostockiej parafii farnej, Wydawnictwo BUK, Białystok 2008, p. 108.

[3] Gossel P., Leuthauser G., Architecture in the $20^{\text {th }}$ Century, Taschen, Köln 2012, p. 337-340.

[4] Kłopotowska A., Kłopotowski M., Architektura białostockich kościołów. Cz. 1. Historia (1617-1980), Teka Komisji Architektury, Urbanistyki i Studiów Krajobrazowych PAN, 2015, vol. 11, nr 1, p. 25-35.

[5] Kucza-Kuczyński K., Święta cegła, Czasopismo Techniczne. Architektura, R. 109, z.5-A/1, Wyd. Politechniki Krakowskiej, Kraków 2012, p. 192-195.

[6] Tietz J., Historia architektury XX wieku, Könemann, Köln 2001, p. 98.

[7] Tokajuk A., Tokajuk E., New life of postindustrial factories in Bialystok - chosen aspects, Teka Komisji Architektury, Urbanistyki i Studiów Krajobrazowych PAN, T. 15 nr 1, 2019, p. 16-27.

[8] Turecki A., Białostocka Szkoła Muratorska, Czasopismo Architekt, nr 5, 2003, p. 40-42.

[9] Włodarczyk J.A., Prawda i kłamstwa architektury, Oficyna Wydawnicza Politechniki Białostockiej, Białystok 2009, p. $164-165$. 